\title{
Functional Expression and Segmental Localization of Rat Colonic K-Adenosine Triphosphatase
}

Jinseon Lee, Vazhaikkurichi M. Rajendran, Andrea S. Mann, Michael Kashgarian, and Henry J. Binder

Departments of Internal Medicine and Pathology, Yale University School of Medicine, New Haven, Connecticut 06520-8019

\begin{abstract}
A putative cDNA for the colonic K-ATPase has recently been cloned (Crowson, M. S., and G. E. Shull. 1992. J. Biol. Chem. 267:13740-13748). Considerable evidence exists that there are two $K$-ATPases and active $K$ absorptive processes in the rat distal colon: one that is ouabain sensitive and the other ouabain insensitive. The present study used the baculovirus expression system to express K-ATPase activity in insect Spodoptera frugiperda $(S f)$ ) cells and a polyclonal antibody (M-1), developed against a fusion protein produced from the 327 nucleotide fragment from $5^{\prime}$ coding region of the putative $K$-ATPase cDNA, to identify the specific localization of the K-ATPase protein. K-ATPase activity $(28.7 \pm 1.2 \mathrm{nmol}$ inorganic phosphate/mg protein $\mathrm{min})$ was expressed in plasma membranes isolated from $S f 9$ cells infected with baculovirus containing recombinant DNA with the putative K-ATPase cDNA. $K_{m}$ for $K$ for the K-ATPase was $1.2 \mathrm{mM}$. The expressed $K$-ATPase activity was not inhibited by ouabain ( $1 \mathrm{mM}$ ); while the $K_{\mathrm{i}}$ for vanadate inhibition was $8.3 \mu \mathrm{M}$. Western blot analysis with the M-1 antibody identified a 100-kD protein in apical membranes prepared from distal, but not proximal, rat colon. Immunohistochemical studies with M-1 antibody localized K-ATPase only in the apical membrane of surface cells, while an mAb (c464.6) against Na,K-ATPase localized basolateral membranes of both surface and crypt cells of rat distal colon. In conclusion, the putative K-ATPase cDNA encodes an ouabain-insensitive K-ATPase that is present only in the apical membrane of surface cells of rat distal colon. ( J. Clin. Invest. 1995. 96:2002-2008.) Key words: colonic K-ATPase - active K absorption - K-H exchange - ouabain sensitivity - Spodoptera frugiperda ( $S f$ 9) cells
\end{abstract}

\section{Introduction}

A family of P-type ATPases has been cloned in which there are substantial similarities in their DNA and deduced amino acid sequences (1-5). These ATPases include Na,K-ATPase, a $\mathrm{H}, \mathrm{K}-\mathrm{ATPase}$ from gastric parietal cell, a H,K-ATPase from toad bladder, and a putative K-ATPase from the rat distal colon.

Address correspondence to Henry J. Binder, Yale University School of Medicine, Department of Internal Medicine, 333 Cedar Street-89 LMP, New Haven, CT 06520-8019. Phone: 203-785-4796; FAX: 203-7857273; E-mail: Binder@biomed.med.yale.edu

Received for publication 17 March 1995 and accepted in revised form 6 July 1995.

J. Clin. Invest.

(C) The American Society for Clinical Investigation, Inc. 0021-9738/95/10/2002/07 \$2.00

Volume 96, October 1995, 2002-2008
There is also suggestive evidence that a related ATPase is present in the kidney and is responsible for both distal tubular $\mathrm{K}$ absorption and proton secretion (6). The three isoforms of the $\alpha$ subunit of Na,K-ATPase, the $\alpha$ subunit of the gastric $\mathrm{H}, \mathrm{K}$ ATPase, and the colonic K-ATPase have an $\sim 50 \%$ homology between their deduced amino acid sequences $(4,7)$. Not surprisingly, these related ATPases have specific characteristics as well as overlapping properties. Thus, $\mathrm{Na}, \mathrm{K}-\mathrm{ATPase}$, the $\mathrm{Na}$ pump, is markedly inhibited by ouabain but is not altered by omeprazole or SCH 28080, inhibitors of both gastric parietal cell $\mathrm{H}, \mathrm{K}$-ATPase and gastric acid secretion (1). In contrast, the gastric $\mathrm{H}, \mathrm{K}$-ATPase is inhibited by omeprazole and by $\mathrm{SCH}$ 28080, while ouabain does not affect this gastric ATPase (8). In the rat distal colon K-ATPase activity overlaps the properties of the gastric ATPase and the Na pump. Thus, the K-ATPase (as well as active $\mathrm{K}$ absorption) in the rat distal colon are partially inhibited by ouabain but are only minimally altered by either omeprazole or SCH 28080 (9-11).

The putative K-ATPase cDNA that was cloned and sequenced from the rat distal colon has a $60-65 \%$ homology with either $\mathrm{Na}, \mathrm{K}-\mathrm{ATPase}$ or gastric $\mathrm{H}, \mathrm{K}$-ATPase $(4,7)$. Initial observations with in situ hybridization studies established that the message of the colonic K-ATPase is restricted to the surface epithelial (and $\sim 20 \%$ of the glandular) cells of the rat distal colon (7). Presently available information suggests that the cDNA from the rat distal colon is that of the $\alpha$ subunit of the apical K-ATPase but, as this cDNA has not been expressed, is not conclusive. Recent studies of both active $\mathrm{K}$ absorption and $\mathrm{K}$-ATPase activity in apical membranes of the rat distal colon strongly indicate that there are two different K-ATPases and active $\mathrm{K}$ absorption processes in the rat distal colon, one that is ouabain insensitive and the other that is ouabain sensitive $(10,11)$. To confirm the identity of the cDNA that has recently been cloned and sequenced from rat distal colon, the present studies were initiated to provide both functional expression of the cDNA from the rat distal colon and insight into the potential functional/structural heterogeneity of the colonic K-ATPase.

\section{Methods}

Preparation of recombinant baculovirus. The XhoI termini of the fulllength cDNA $(4 \mathrm{~kb})$ of the putative $\mathrm{K}$-activated ATPase in the pBluescript $\mathrm{KS}(+)$ (provided by Crowson, M. S. and G. E. Shull, University of Cincinnati, Cincinnati $\mathrm{OH}$ [4]) was modified with oligonucletide adaptors and subcloned at BamHI site in a pBacPAK1 transfer vector (Clontech, Palo Alto, CA). The recombinant with sense orientation from baculovirus polyhedron promoter was selected and the plasmid DNA was prepared (12).

Lipofectin-DNA complex was prepared by mixing the recombinant DNA, Bsu361-digested BacPAK6 baculoviral DNA (Clontech), and Lipofectin (GIBCO-BRL, Gaithersburg, MD), and incubating at room temperature for $15 \mathrm{~min}$. 50\%-saturated Spodoptera frugiperda ( $S f 9)$ cell monolayer was rinsed with serum-free Grace medium (GIBCOBRL) and transfected with the Lipofectin-DNA complex for $5 \mathrm{~h}$. After 
addition of $3 \mathrm{ml} \mathrm{10 \%} \mathrm{FBS-Grace} \mathrm{medium} \mathrm{and} \mathrm{incubation} \mathrm{for} 72 \mathrm{~h}$, the culture supernatant was collected and stored at $4^{\circ} \mathrm{C}$. Additional supernatant was collected after further addition of $5 \mathrm{ml} 10 \%$ FBSGrace's medium and incubation for $48 \mathrm{~h}$. The pooled culture supernatants were tested for the presence of non-recombinant baculovirus particles by incubating an aliquot of supernatant with X-gal (Statagene, La Jolla, CA) (3\% X-gal in dimethylformamide, diluted 10-fold in PBS) overnight at room temperature.

Plaque purification of recombinant baculovirus. Host cell monolayers were grown in 96-well plates. After removal of all liquid medium, each well was infected with $5 \mu \mathrm{l}$ inoculum containing various concentrations of harvested recombinant virus stock and incubated for $1 \mathrm{~h}$. Diluent medium without virus added to cell monolayer was used as a negative control. After addition of $140 \mu \mathrm{l}$ of $10 \%$ FBS-Grace's medium mixed with $70 \mu \mathrm{l}$ of X-gal and 4-5 d incubation, wells without blue plaques from the highest dilution of viral stock were screened by inverted phasecontrast microscopy to ensure that any colorless occlusion in the well was derived from single virus particles, and the supernatant was collected and stored at $4^{\circ} \mathrm{C}$.

The subconfluent cell monolayer was infected for $1 \mathrm{~h}$ with viral suspension derived from a single well and incubated for 4-5 d. The supernatant of each monolayer was collected and saved as a stock of each viral clone. Genomic DNA of each clone was analyzed for retention of 4-kb BamHI fragment using 3' untranslated region (positions 33843942 ) of the putative K-ATPase cDNA as a probe. Viral clone with a single 4-kb band in Southern analysis was selected.

Expression of the putative K-ATPase cDNA. Approximately 5 $\times 10^{4}$ infectious particles of BacPAK6 or BacPAK6-cDNA virus were added to the $50 \%$ confluent cell monolayer in a T-75 flask. After $4 \mathrm{~d}$ amplification the cells were washed twice with PBS and resuspended in buffer $(20 \mathrm{mM}$ Tris- $\mathrm{HCl}$ buffer, $\mathrm{pH} 7.4,250 \mathrm{mM}$ sucrose, $1 \mathrm{mM}$ EDTA, $0.1 \mathrm{mM}$ PMSF, and $0.1 \mathrm{mM}$ DTT). The cells were lysed by sonication $(3 \times 15 \mathrm{~s}$ at 30 -s intervals at full speed $)$, and the plasma membranes were precipitated by centrifugation at $15,000 \mathrm{rpm}$ for 30 min (RC 5B, SS34 rotor; Sorvall Instruments Div., DuPont Co., Newton, CT). Final pellet was resuspended in buffer and used for Western blot analysis and enzyme assays.

$\mathrm{Mg}$-ATPase, K-ATPase, and Na,K-ATPase activities were measured by the method of del Castillo et al. as previously described (11). The composition of the incubation medium contained (final concentration in millimolar) 50 Tris- $\mathrm{HCl}$, $\mathrm{pH} 7.4,5 \mathrm{MgCl}_{2}$ (and, as required, $25 \mathrm{KCl}$ or $25 \mathrm{KCl}$ and $100 \mathrm{NaCl}$ ). Protein was measured by the method of Lowry et al. (13). ATPase activity was expressed as nanomoles of inorganic phosphate $\left(P_{i}\right)$ liberated/milligram protein per min.

Subconfluent cell monolayers, infected with recombinant baculovirus, amplified for $4 \mathrm{~d}$ in slide chambers, were washed $(2 \times \mathrm{PBS})$, and fixed with paraformaldehyde-lysine-periodate (PLP) as described by Van Why et al. (14) and used for immunohistochemistry.

Production of antibody. The putative K-ATPase cDNA was used as a template to generate a 327-nucleotide DNA fragment beginning from $5^{\prime}$ end of the coding region. Sense (5'-CCGGATCCATGCGCCGGAAAACAGAA-3') and antisense (5'-CCGAATTCCATCTGCTTGAGGAACTT-3') PCR primer oligonucleotides were synthesized by DNA Synthesis Laboratory, Yale University. PCR product digested with BamHI and EcoRI was gel purified and ligated into the glutathione$S$-transferase-expression vector, pGEX-2T, that was predigested with BamHI and EcoRI and dephosphorylated with calf intestine alkaline phosphatase (Pharmacia LKB Biotechnology Inc., Piscataway, NJ). The ligated vector was transformed into Escherichia coli DH5a (GIBCOBRL), and a positive recombinant-containing cDNA fragment with sense orientation was selected.

Positive recombinants were grown in Luria broth-ampicillin medium to an $\mathrm{A}_{600}$ of 1.0 and induced for $2 \mathrm{~h}$. in $1 \mathrm{mM}$ isopropyl $\beta$-Dthiogalactopyranoside. The cells were centrifuged, washed in $50 \mathrm{mM}$

1. Abbreviations used in this paper: $\mathrm{P}_{\mathrm{i}}$, inorganic phosphate; PLP, paraformaldehyde-lysine-periodate; $S f 9$, Spodoptera frugiperda cells.
Tris, $\mathrm{pH} 8.0,50 \mathrm{mM}$ EDTA, and suspended in lysis buffer $(50 \mathrm{mM}$ Tris, pH 8.0, $100 \mathrm{mM} \mathrm{NaCl}, 2 \mathrm{mM}$ EDTA, $2 \mathrm{mM}$ EGTA, $5 \mathrm{mM}$ DTT, $10 \mu \mathrm{g} / \mathrm{ml}$ Leupeptin [Calbiochem Corp., La Jolla, CA], $10 \mu \mathrm{g} /$ $\mathrm{ml}$ Aprotinin [United States Biochemical Corp., Cleveland, $\mathrm{OH}$ ], $1 \mathrm{mM}$ benzamidine, $1.5 \mathrm{mM}$ PMSF, and $1 \mathrm{mg} / \mathrm{ml}$ lysozyme), mixed $45 \mathrm{~min}$ at $4^{\circ} \mathrm{C}$, frozen at $-80^{\circ} \mathrm{C}$, thawed, and maintained at $4^{\circ} \mathrm{C}$ for further manipulations. Final concentrations of $1.0 \%$ Triton X-100, $10 \mathrm{mM}$ $\mathrm{MgCl}_{2}$, and $0.1 \mathrm{mg} / \mathrm{ml}$ DNAaseI (Sigma Chemical Co., St. Louis, MO) were added and incubation continued for $30 \mathrm{~min}$ at $4^{\circ} \mathrm{C}$. After centrifugation, the supernatant was applied to a slurry of glutathione-agarose beads (Sigma Chemical Co.) and allowed to mix by rotation for $1 \mathrm{~h}$ at $4^{\circ} \mathrm{C}$. The beads were sequentially washed in PBS, PBS plus $1.0 \%$ Triton X100 , and $50 \mathrm{mM}$ Tris ( $\mathrm{pH} 8.0$ ), $1 \mathrm{mM}$ EDTA by gentle centrifugation. Fusion protein was eluted after incubation for $15 \mathrm{~min}$ at $4^{\circ} \mathrm{C}$, in 10 $\mathrm{mM}$ reduced glutathione, $\mathrm{pH} 8.0$, dialyzed against $\mathrm{PBS}$ at $4^{\circ} \mathrm{C}$, and concentrated using a Centriprep 10 (Amicon Corp., Beverly, MA).

Antibodies were produced in a New Zealand White rabbit after primary subcutaneous injection of affinity-purified fusion protein ( 400 $\mu \mathrm{g})$ in CFA, and three subsequent boosts of fusion protein $(400 \mu \mathrm{g})$ in incomplete Freund's adjuvant. The antibody produced in this study was designated $\mathbf{M}-1$

Western blots. SDS-PAGE was performed by the standard procedure. To avoid aggregation the protein samples of rat distal colon apical membranes were warmed to $37^{\circ} \mathrm{C}$ for 20 min before loading. Proteins were electrophoretically transferred from SDS-PAGE to nitrocellulose (Biotrace; Gelman Sciences Inc., Ann Arbor, MI) in $192 \mathrm{mM}$ glycine,

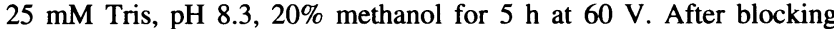
nonspecific sites with TBST consisting of $10 \mathrm{mM}$ Tris, $\mathrm{pH} 8.0,150$ $\mathrm{mM} \mathrm{NaCl}, 0.05 \%$ Tween-20, and $1 \% \mathrm{BSA}$, immunostaining was performed with antibody M-1, diluted 500-fold in TBST and alkaline phosphatase-conjugated anti-rabbit IgG at a 7,500-fold dilution in TBST. Antibody-specific bands were visualized by Western blue detection (Promega Corp., Madison, WI).

Immunohistochemistry. Rats were fixed via whole body ventricular perfusion with PLP fixative for 2 min. Colon was removed as quickly as possible, dissected into millimeter-sized pieces which were postfixed for $1 \mathrm{~h}$ at room temperature in PLP. The fixation was followed by three 15-min washes in PBS. Tissue was then cryo-protected in PBS 10\% DMSO for $10 \mathrm{~min}$ and frozen in individual pieces under swirling Freon22 which was undercooled to approximately $-100^{\circ} \mathrm{C}$ with liquid nitrogen. Tissue was stored under liquid nitrogen until use. Tissue was then cut on a cryostat (AO; Reichert Scientific Instruments, Buffalo, NY) at $6-\mu \mathrm{m}$ thickness and picked up on lysine-coated slides. Sections were then rehydrated and blocked with PBS, $1 \%$ BSA, $1 \%$ normal goat serum for $1 \mathrm{~h}$ at room temperature. The slides were then further blocked using an avidin-biotin-blocking kit from Vector Laboratories (Burlingame CA) per standard instruction. Tissue was then incubated in sequential series of primary antibodies M-1 and C464.8 (15), diluted in PBS, $0.1 \% \mathrm{BSA}$, and normal goat serum for $1 \mathrm{~h}$ in a humidified chamber at room temperature. Sections were then washed three times for $15 \mathrm{~min}$ each. Biotinylated anti-rabbit antibody (Vector Laboratories), was diluted 1:100 in PBS and incubated and washed as above. Strepavidinconjugated (Sigma) Texas red and FITC-labeled goat anti-mouse Ig (1:200) was then applied, and sections were washed. Slides were then coverslipped using a fade-resisting medium (Vectashield; Vector Laboratories) and edged sealed with Cytoseal Mounting medium (Stephens Scientific, Riverdale, NJ). Slides were stored at $4^{\circ} \mathrm{C}$ until viewing.

Confocal microscopy. Confocal microscopy was performed with a scanning head (MRC-600; Bio-Rad Laboratories, Richmond, CA) using a double label FITC-Texas red filter set attached to a standard upright microscope (Carl Zeiss, Thornwood, NY) fitted with a $\times 50$ water immersion lens (E. Leitz, Inc., Rockleigh, NJ). This allowed for simultaneous detection and video display of both fluorochromes so that identical areas of tissue were imaged. All microscope settings controlling laser intensity, detection sensitivity, and confocal aperture size were standardized to insure optimal signal to noise for double-labeled tissue. Negative control, positively labeled normal, and experimental tissue were then viewed under identical conditions. 


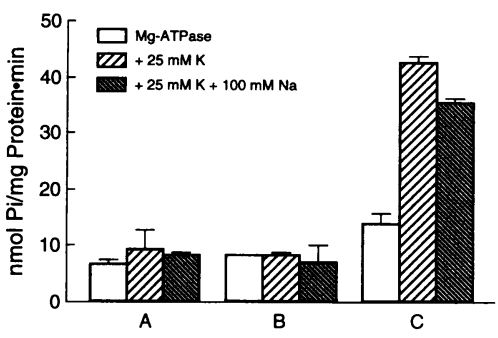

Figure 1. K-activated ATPase activity in $S f 9$ cells infected with baculovirus containing recombinant DNA with the putative K-ATPase cDNA. (A) ATPase activities were measured in normal $S f 9$; (B) $S f 9$

cells infected with nonre-

combinant DNA containing virus; and $(C) S f 9$ cells infected with virus containing the recombinant DNA. $S f 9$ cells were harvested and plasma membranes were prepared as described in Methods. Both plasma membranes and supernatant (not shown) were used for enzyme assay. Values are mean $\pm \mathrm{SE}$ of triplicate assay of membranes from two different preparations and are expressed as nanomoles $\mathrm{P}_{\mathrm{i}}$ liberated/milligram protein per min. Mg-ATPase activity was present in all three groups of $S f 9$ cells. Addition of $25 \mathrm{mM} \mathrm{K}$ stimulated ATPase activity only in $S f 9$ cells infected with baculovirus containing recombinant DNA. Na,KATPase activity was not present in any of the three groups of $S f 9$ cells.

\section{Results}

The full-length cDNA of the putative K-ATPase was transferred downstream to the polyhedron promoter in the baculovirus transfer vector which carries genes for viral multiplication. Host insect cells (Spodoptera frugiperda, $S f$ 9) were coinfected with the recombinant transfer vector and the linearized baculoviral genome deficient of genes essential for the viral multiplication. The enriched replicable recombinant baculoviruses were purified and tested for nonocclusion of the dye, X-gal, to eliminate possible contamination of the reverted parental virus. Southern analysis using the radiolabeled 3' untranslated region of the putative K-ATPase cDNA revealed that the intact size of DNA was retained in the recombinant baculovirus-infected cells; DNA from uninfected and parental nonrecombinant baculovirus-infected cells served as negative controls (data not shown).

To determine whether the cloned putative colonic K-ATPase cDNA expresses functional proteins with ATPase activity, $S f 9$ cells were infected with baculovirus with recombinant DNA containing the full-length putative K-ATPase cDNA (Fig. 1
$C$ ); uninfected $S f 9$ cells (Fig. $1 A$ ) and $S f 9$ cells infected with baculovirus without recombinant DNA (Fig. $1 B$ ) were used as controls. Crude plasma membranes from the homogenates of Sf 9 cells of all three conditions were obtained by high speed centrifugation and used for measurement of Mg-ATPase, KATPase, and $\mathrm{Na}, \mathrm{K}-\mathrm{ATPase}$ activities. As shown in Fig. 1, MgATPase activity was expressed in plasma membranes of $S f 9$ cells in all three conditions, while K-ATPase activity was expressed only in $S f 9$ cells infected with baculovirus containing the recombinant DNA. Plasma membranes of $S f 9$ cells isolated from the other two conditions did not express K-ATPase activity. $\mathrm{Na}, \mathrm{K}$-ATPase activity was not expressed in any of the $S f 9$ cells. Neither K-ATPase nor Na,K-ATPase activities were present in the supernatant derived from the homogenates of these Sf 9 cells (data not shown). Further, immunohistochemical studies indicate that the M-1 antibody (see below) binds to both cytoplasmic membranes and outer membrane of the $S f 9$ cells infected with baculovirus containing recombinant DNA (Fig. $2 B$ ) but did not bind to membranes of $S f 9$ cells that were not infected or infected with baculovirus without recombinant DNA (data not shown). Therefore, these results indicate that the putative K-ATPase cDNA of rat distal colon encodes a membrane-bound protein with functional K-ATPase activity. Subsequent studies were performed only with $S f 9$ cells infected with recombinant DNA.

Studies were performed to establish the characteristics of the K-ATPase activity expressed in the plasma membranes of Sf 9 cells infected with recombinant DNA. The effect of increasing $\mathrm{K}$ concentration on $\mathrm{K}$-activated ATPase activity was assessed to establish its affinity constant $\left(K_{\mathrm{m}}\right)$. Fig. 3 demonstrates that $\mathrm{K}$-activated ATPase activity increased as $\mathrm{K}$ concentrations increased. The calculated $K_{\mathrm{m}}$ of $\mathrm{K}$-activated ATPase was $\sim 1.2$ $\mathrm{mM}$, while $\mathrm{K}$-activated ATPase activity was maximal at $\mathrm{K}$ concentrations above $5 \mathrm{mM}$. The $K_{\mathrm{m}}$ of the ouabain-insensitive fraction of $\mathrm{K}$-activated ATPase in native apical membranes from rat distal colon was $0.75 \mathrm{mM}$ (11) with maximal activity observed at $\mathrm{K}$ concentrations above $5 \mathrm{mM}$. The effect of putative ATPase inhibitors, vanadate, ouabain, and SCH 28080, was also examined on K-ATPase activity of $S f 9$ cells and compared to K-ATPase activity of the colonic apical membranes (11) (Table I). K-ATPase activity of $S f 9$ cells and colonic apical
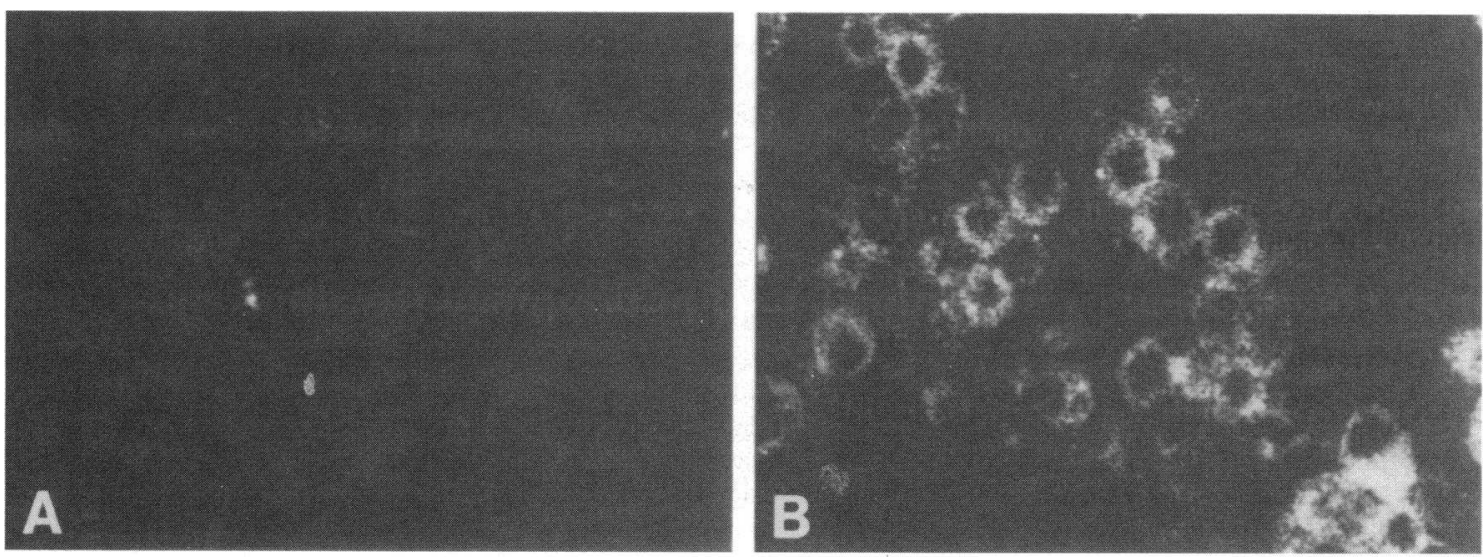

Figure 2. Immunohistochemical studies of $S f 9$ cells. Sf 9 cells were fixed in PLP and processed as described in Methods. ( $A$ ) Recombinant baculovirus-transfected $S f 9$ cells, with no primary antibody, served as a negative control for $(B)$ in which recombinant baculovirus-infected $S f 9$ cells were stained with M-1 antibody and which demonstrated antibody localization to the cytoplasm and plasma membrane. M-1 was diluted 1:25. All samples were then stained with rhodamine-conjugated species-specific secondary antibody and examined by confocal microscopy $(\times 500)$. 


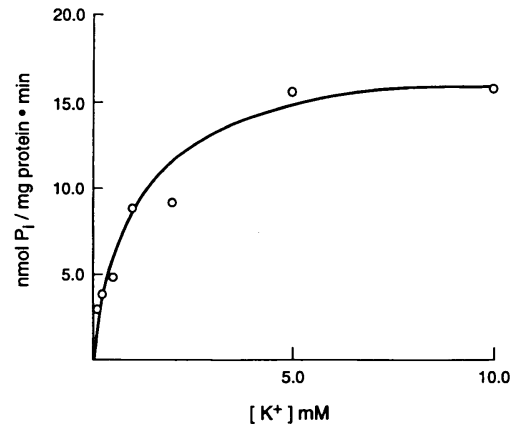

The apparent $K_{\mathrm{m}}$ for $\mathrm{K}$ was $1.2 \mathrm{mM}$. The $K_{\mathrm{m}}$ was calculated by Lineweaver-Burk plot. The figure shown was fitted by using the MichaelisMenton equation.

membranes was inhibited $100 \%$ by $0.1 \mathrm{mM}$ vanadate (Table I) with $K_{\mathrm{i}}$ 's of 8.3 and $13.6 \mu \mathrm{M}$, respectively (data not shown). In addition, $\mathrm{SCH} 28080$, a potent inhibitor of gastric H,K-ATPase activity, inhibited K-ATPase activity in $S f 9$ cells and colonic apical membranes by 18 and $24 \%$, respectively (Table I).

$1 \mathrm{mM}$ ouabain inhibited K-ATPase activity of colonic apical membrane by $75 \%$, similar to our earlier report (11) and consistent with the presence of both ouabain-sensitive and ouabaininsensitive fractions. In contrast, K-ATPase activity of $S f 9$ cells was not inhibited by $1 \mathrm{mM}$ ouabain suggesting that the $\mathrm{K}$ ATPase expressed in $S f 9$ cells represents the ouabain-insensitive, not the ouabain-sensitive, fraction.

To establish the specific membrane localization (i.e., apical membrane vs basolateral membrane) and regional localization along surface-crypt axis of rat distal colon, antibodies were produced against a specific polypeptide region of the putative K-ATPase cDNA and used for Western blot (Fig. 4) and immunohistochemical (Fig. 5) analyses. The first 327 bp of the coding region of the putative K-ATPase cDNA was expressed as a fusion protein in small PGEX-2T vector. The purified fusion protein was used to elicit polyclonal antibodies (designated as M-1 antibody) in rabbit. As shown in Fig. 4, the M-1 antibody recognizes a $100-\mathrm{kD}$ protein in apical membranes of distal colon but did not identify any proteins in either apical membranes of proximal colon or basolateral membranes of distal colon (data not shown). Immunohistochemical analysis of rat distal colon indicates that M-1 antibody binds only to the apical membranes

Table I. Effect of Inhibitors on K-activated ATPase Activity*

\begin{tabular}{lcc}
\hline & ${\text { Transfected } S f 9 \text { cells }^{\ddagger}}$ & Colonic apical membranes $^{s}$ \\
\hline & \multicolumn{2}{c}{$n$ mol $P_{i}$ liberated/mg protein per min } \\
Control & $30.4 \pm 0.9$ & $167.7 \pm 4.1$ \\
+ vanadate $(0.1 \mathrm{mM})$ & $-0.3 \pm 1.1^{\| 1}$ & $-25.1 \pm 13.1^{\|}$ \\
+ ouabain $(1 \mathrm{mM})$ & $34.4 \pm 1.3$ & $43.7 \pm 6.9^{\|}$ \\
+ SCH $28080(0.1 \mathrm{mM})$ & $25.1 \pm 1.3^{\natural}$ & $127.4 \pm 6.7^{* *}$ \\
\hline
\end{tabular}

* Mean \pm SE of triplicate values; ${ }^{\ddagger}$ membranes from cells that have been infected with baculovirus containing recombinant DNA with the putative K-ATPase cDNA (see Methods for details); ${ }^{\S}$ apical membrane vesicles prepared from rat distal colon as previously described (23); ${ }^{\|} P<0.001$ compared to control; $1 P<0.05$ compared to control; ${ }^{* *} P<0.01$ compared to control.

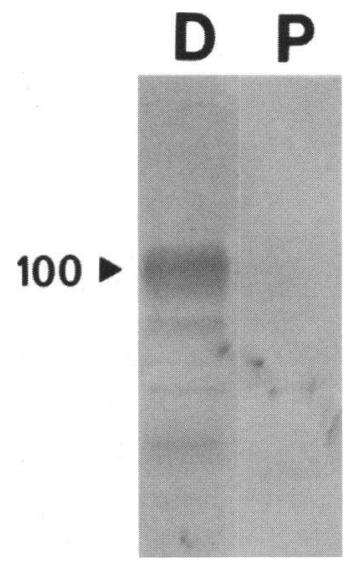

Figure 4. Western Blot analysis of apical membranes prepared from rat proximal $(P)$ and distal $(D)$ colon. Blot was stained with M-1 diluted antibody (1:500), followed by an alkaline phosphatase-conjugated secondary antibody as described in Methods. The arrow identifies a $100-\mathrm{kD}$ protein.

of surface cells but not to crypt cells (Fig. $5 \mathrm{~B}$ ). There was no evidence of immunoreactivity in proximal colon (Fig. $5 \mathrm{D}$ ). Parallel immunohistochemical studies were performed with an antibody to the $\alpha$ subunit of Na,K-ATPase (15). This antibody is bound to basolateral membranes of both surface and crypt cells of both proximal and distal colon but not to the apical membranes (Fig. 5, $A$ and $C$ ). These results indicate that the putative K-ATPase cDNA expresses a surface cell-specific apical membrane K-ATPase that is restricted to the distal colon with a distribution that is distinct from that of $\mathrm{Na}, \mathrm{K}$-ATPase.

Additional studies were performed to determine whether the M-1 antibody has biological activity by determining its ability to alter K-ATPase activity in colonic apical membranes. As shown in Fig. 6, the M-1 antibody produced a dose-dependent inhibition of apical membrane K-activated ATPase activity; 25 $\mu \mathrm{g} / \mathrm{ml} \mathrm{M}-1$ antibody completely inhibited both the ouabainsensitive and ouabain-insensitive component of the colonic enzyme activity (Fig. 6). In contrast, M-1 antibody did not inhibit highly purified $\mathrm{Na}, \mathrm{K}-\mathrm{ATPase}$ activity prepared from rabbit renal medulla (16). In parallel experiments with homogenates from Sf 9 cells $25 \mu \mathrm{g} / \mathrm{ml}$ antibody also completely inhibited K-activated ATPase activity.

\section{Discussion}

Studies of colonic potassium transport in rat, rabbit, and guinea pig have established that active $\mathrm{K}$ absorption is present in the distal, but not proximal, large intestine and is energized by an apical membrane K-ATPase $(9,10,17-19)$. Both active $\mathrm{K}$ absorption and K-ATPase activity are partially inhibited by ouabain, and functional studies strongly suggest that there may be two active $\mathrm{K}$ absorption/K-ATPase systems, e.g., one that is inhibited by ouabain and the other that is ouabain insensitive $(10,11)$. It is likely that the recently isolated cDNA from rat distal colon represents the transport protein for active $\mathrm{K}$ absorption/K-ATPase. First, there is partial homology between the deduced amino acid sequences of this cDNA and those of $\mathrm{Na}, \mathrm{K}$-ATPase and gastric H,K-ATPase $(3,7)$. Second, Northern blot analyses with this cDNA revealed hybridization to mRNA isolated from distal, but not proximal, colon $(3,7)$, which is identical to the distribution of both apical K-ATPase and active $\mathrm{K}$ absorption $(11,17)$. Third, in situ hybridization studies using the colonic cDNA have localized the K-ATPase message to the surface epithelial cells of the rat distal colon 

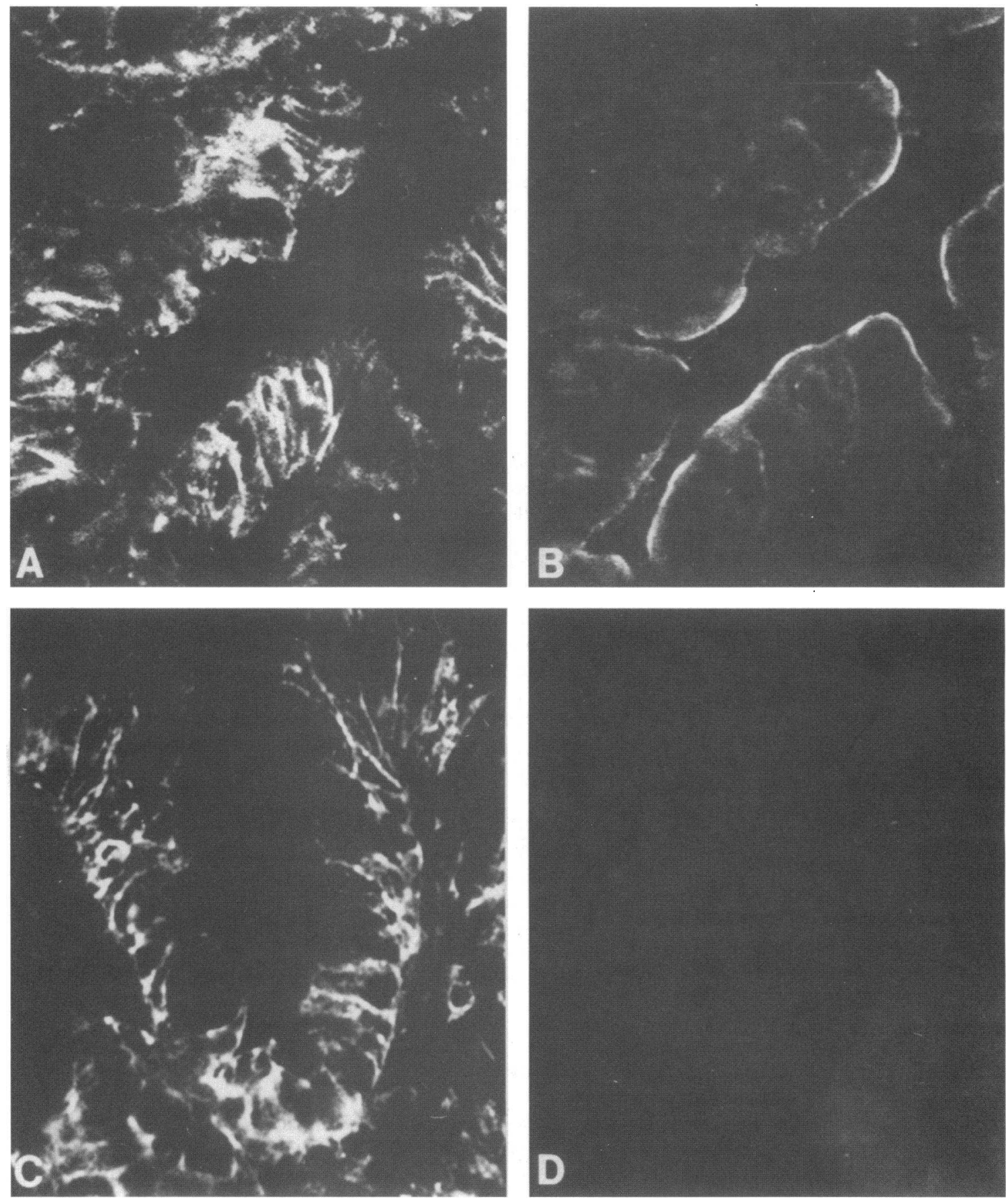

Figure 5. Immunohistochemical studies of colonic mucosa. Colonic tissue was fixed in PLP and processed as described in Methods. K-ATPase is restricted to the apical membranes of distal colon. $(A$ and $B$ ) Distal colon was double labeled for $(A)$ Na,K-ATPase (with C464.8-FITC) and $(B)$ colonic K-ATPase (with M-1-Texas red). Na,K-ATPase is localized to the basal and lateral membranes of all cells, while K-ATPase is restricted to the apical membranes of cells of the epithelium of the surface and upper third of the crypts. $(C$ and $D$ ) Proximal colon was also double labeled with the same antibodies. While Na,K-ATPase has the same localization as in the distal colon, there is no localization of the K-ATPase in the proximal colon. M-1 was diluted 1:25, while $\mathrm{C} 464.6$ was diluted 1:50. $\times 500$.

(7). All these observations are consistent with this cDNA expressing at least one isoform of the colonic K-ATPase.

To establish that the isolated colonic cDNA expressed the transport proteins for colonic $\mathrm{K}$ absorption/K-ATPase we used a baculovirus system that is capable of expressing substantial amounts of foreign protein in insect cells. The expressed protein from these cells contained K-ATPase activity that had properties similar to that previously identified in native colonic tissue (11). First, potassium markedly stimulated Mg-ATPase activity without any evidence of Na,K-ATPase activity (Fig. 1). Second, K activation of ATPase activity in $S f 9$ cells (Fig. 3) was similar to that previously observed in apical membranes from rat distal colon (11). Third, vanadate completely inhibited the K-ATPase activity indicating that the expressed protein was a P-type 


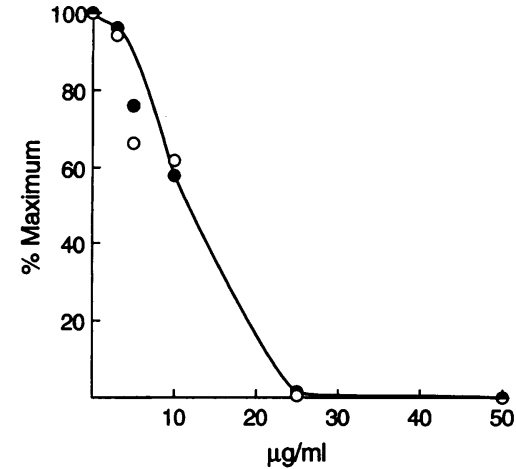

Figure 6. Effect of antibody on K-ATPase activities in apical membranes prepared from normal rat distal colon. Membranes mixed with different antibody concentrations were incubated at $37^{\circ} \mathrm{C}$ for $60 \mathrm{~min}$. Incubation mixtures were again treated with SDS as described in Methods and used for enzyme measurements. ATPase ac-

tivities were measured in presence of $\mathrm{Mg}, \mathrm{Mg}$ plus $\mathrm{K}$, and plus $1 \mathrm{mM}$ ouabain. K-activated ATPase activity represents the difference in activity between that in the presence of $\mathrm{Mg}$ plus $\mathrm{K}$ and that in the presence of $\mathrm{Mg}$ alone. Ouabain-sensitive activity is the difference between total activity and that determined in presence of ouabain (closed circles), while ouabain-insensitive activity (open circles) is that activity determined in presence of ouabain.

ATPase (Table I). Further, the $K_{\mathrm{i}}$ 's for vanadate inhibition of K-ATPase were identical in $S f 9$ cells and colonic apical membranes. Fourth, the K-ATPase activity of both the expressed protein and apical membranes isolated from rat distal colon was partially reduced by SCH 28080 , an inhibitor of parietal cell H,K-ATPase (Table I). Fifth, although K-ATPase in apical membranes isolated from native distal colon has both ouabain-sensitive and ouabain-insensitive fractions ([11] and Table I), the K-ATPase activity of the expressed protein was ouabain insensitive. As a result, it is likely that this isolated cDNA $(3,7)$ encodes the colonic ouabain-insensitive K-ATPase and not the ouabain-sensitive fraction. This observation is also consistent with the previous conclusion that there were two different $\mathrm{K}$-ATPases and/or active $\mathrm{K}$ absorptive processes in the distal colon $(10,11)$. Thus, we predict the existence of an ouabain-sensitive colonic K-ATPase.

Both $\mathrm{Na}, \mathrm{K}$-ATPase and parietal cell $\mathrm{H}, \mathrm{K}$-ATPase consist of unique $\alpha$ and $\beta$ subunits. Although the $\alpha$ subunit possesses the catalytic site, both subunits are required for enzymatic activity. A $\beta$ subunit for the colonic K-ATPase has not been identified, and K-activated ATPase activity was demonstrated in $S f 9$ cells infected only with the $\alpha$ subunit cDNA (Fig. 1 and Table I) suggesting that a $\beta$ subunit may not be required for colonic K-ATPase activity. Previous studies of Na,K-ATPase in $S f 9$ cells may have relevance to the present studies in that infection of $S f 9$ cells by $\alpha 2$ or $\alpha 3$ subunit of Na,K-ATPase resulted in the synthesis of membrane bound protein (20). In contrast to the present results (Fig. 1), a minimal though finite level of $\mathrm{Na}, \mathrm{K}$-ATPase activity was present in uninfected $S f 9$ cells (20). A substantial increase in $\mathrm{Na}, \mathrm{K}$-ATPase activity occurred only when $\beta$ subunit was coinfected with either $\alpha 2$ or $\alpha 3$ subunit. It is not known whether the expression of K-ATPase activity after infection by the colonic cDNA (Fig. 1) was a result of $\mathrm{K}$-ATPase functioning independent of a $\beta$ subunit or to the presence in the $S f 9$ cells of an endogenous $\beta$ subunit for $\mathrm{Na}, \mathrm{K}$ ATPase. This latter possibility is suggested by the demonstration that the $\beta$ subunits of Na,K-ATPase and H,K-ATPase can serve as partial surrogates in the activation of both H,K-ATPase and $\mathrm{Na}, \mathrm{K}-\mathrm{ATPase}$ activities, respectively (21). This suggestion is further supported by the previous observation that an antibody to the $\beta$ subunit of $\mathrm{Na}, \mathrm{K}-\mathrm{ATPase}$ identified a protein in the apical membrane of rat distal colon (22). Further studies of the role of a putative colonic K-ATPase $\beta$ subunit are required.

To localize the colonic K-ATPase, antibodies were raised against a fusion protein encoded by the first $327 \mathrm{bp}$ of the coding region. These present results provide compelling evidence that antibody M-1 is directed against the colonic K-ATPase. First, this antibody recognized a $100-\mathrm{kD}$ apical membrane protein from the distal, but not the proximal, rat colon on Western blot (Fig. 4). Second, immunohistochemical studies localized colonic K-ATPase to the apical membrane of the surface epithelial cells of the rat distal colon and to the plasma membrane of Sf 9 cells infected with baculovirus containing recombinant DNA (Figs. 2 and 5). There was no immunolocalization either to the basolateral membrane of distal colon, to the luminal surface of crypt epithelial cells of distal colon, or to proximal colonic epithelial cells (Fig. 5). A similar distribution was noted in in situ hybridization studies with this cDNA (7). Third, this antibody has biologic activity in that K-ATPase activity in both apical membranes and $S f 9$ cells infected with recombinant virus was completely inhibited by this antibody (Fig. 6). This antibody is highly specific for K-activated ATPase in that M-1 antibody did not alter $\mathrm{Na}, \mathrm{K}$-ATPase activity while partially inhibiting gastric H,K-ATPase activity (unpublished observations). Since the antibody inhibited both the ouabain-sensitive and the ouabain-insensitive fractions (Fig. 6), it is likely that this antibody is directed against an epitope that is not required for determination of ouabain sensitivity.

In conclusion, these studies established that the previously isolated colonic cDNA $(3,7)$ encodes the $\alpha$ subunit of the colonic ouabain-insensitive K-ATPase and that an antibody has been isolated against this ATPase. The tissue and cellular distribution of the message $(3,7)$ and protein (Figs. 4 and 5) and functional characteristics of the expressed protein (Fig. 1 and Table I) support this conclusion. Since the expressed K-ATPase was not sensitive to ouabain, we predict the existence of a second colonic K-ATPase that is ouabain-sensitive.

\section{Acknowledgments}

The authors acknowledge the excellent assistance of Thomas Adito who performed the immunohistochemical studies. Ms. Mary Guidone provided excellent secretarial assistance.

This study was supported in part by U.S. Public Health Service research grant DK 18777 from the National Institute of Diabetes, Digestive and Kidney Diseases.

\section{References}

1. Horisberger, J. D., V. Lemas, H. P. Kraehenbuhl, and B. C. Rossier. 1991. Structure-function relationship of Na,K-ATPase. Annu. Rev. Physiol. 53:565584.

2. Lingrel, J. B., J. Orlowski, M. M. Shull, and E. M. Price. 1991. Molecular genetics of Na,K-ATPase. Prog. Nucleic Acid Res. Mol. Biol. 38:37-89.

3. Shull, G. E., and J. B. Lingrel. 1986. Molecular cloning of the rat stomach $\left(\mathrm{H}^{+}+\mathrm{K}^{+}\right)$-ATPase. J. Biol. Chem. 261:16788-16791.

4. Crowson, M. S., and G. E. Shull. 1992. Isolation and characterization of a cDNA encoding the putative distal colon $\mathrm{H}^{+}, \mathrm{K}^{+}$-ATPase: similarity of deduced amino acid sequence to gastric $\mathrm{H}^{+}, \mathrm{K}^{+}$-ATPase and $\mathrm{Na}^{+}, \mathrm{K}^{+}$-ATPase and messenger RNA expression in distal colon, kidney, and uterus. J. Biol. Chem. 267:1374013748 .

5. Jaisser, F., J. D. Horisberger, K. Geering, and B. C. Rossier. 1993. Mechanisms of urinary $\mathrm{K}^{+}$and $\mathrm{H}^{+}$excretion: primary structure and functional expression of novel H,K-ATPase. J. Cell Biol. 123:1421-1429.

6. Wingo, C. S., and B. D. Cain. 1993. The renal H-K-ATPase: physiological significance and role in potassium homeostasis. Annu. Rev. Physiol. 55:323-347.

7. Jaisser, F., N. Country, N. Farman, H. J. Binder, and B. C. Rossier. 1993. 
A putative $\mathrm{H}^{+}-\mathrm{K}^{+}$-ATPase is selectively expressed in surface epithelial cells of rat distal colon. Am. J. Physiol. 265:C1080-C1089.

8. Sachs, G. 1994. The gastric H,K-ATPase. Regulation and structure/function of acid pump of the stomach. In Physiology of the Gastrointestinal Tract. 3rd ed. L. R. Johnson, editor. 1119-1138.

9. Sweiry, J., and H. J. Binder. 1990. Active potassium absorption in rat distal colon. J. Physiol. (Lond.). 423:155-170.

10. Pandiyan, V., V. M. Rajendran, and H. J. Binder. 1992. Mucosal ouabain and $\mathrm{Na}^{+}$inhibit active $\mathrm{Rb}^{+}\left(\mathrm{K}^{+}\right)$absorption in normal and sodium-depleted rat colon. Gastroenterology. 102:1846-1853.

11. Del Castillo, J. R., V. M. Rajendran, and H. J. Binder. 1991. Apical membrane localization of ouabain-sensitive $\mathrm{K}^{+}$-activated ATPase activities in rat distal colon. Am. J. Physiol. 261:G1005-G1011.

12. Sambrook, J., E. Fritsch, and T. Maniatis. 1989. Molecular Cloning: A Laboratory Manual. 2nd ed. Cold Spring Harbor Laboratory, Cold Spring Harbor, NY.

13. Lowry, O. H., N. J. Rosebrough, A. N. Farr, and R. J. Randall. 1951. Protein measurement with the folin phenol reagent. J. Biol. Chem. 193:265-275.

14. Van Why, S. K., A. S. Mann, T. Ardito, N. J. Siegel, and M. Kashgarian. 1994. Expression and molecular regulation of $\mathrm{Na}^{+}-\mathrm{K}^{+}$-ATPase after renal ischemia. Am. J. Physiol. 267:F75-F85.

15. Van Why, S. K., F. Hildebrandt, T. Ardito, A. S. Mann, N. J. Siegel, and M. Kashgarian. 1992. Induction and intracellular localization of HSP-72 after renal ischemia. Am. J. Physiol. 263:F769-F775.

16. Jorgensen, P. L. 1974. Purification and characterization of $\left(\mathrm{Na}^{+}-\mathrm{K}^{+}\right)-$
ATPase III purification from the outer medulla of mammalian kidney after selective removal of membrane components by $\mathrm{Na}$ doceylsulphate. Biochim. Biophys. Acta. 356:36-52.

17. Foster, E. S., H. P. Hayslett, and H. J. Binder. 1984. Mechanism of active potassium absorption and secretion in the rat colon. Am. J. Physiol. 246:G611G617.

18. Wills, N. K., and B. Biagi. 1982. Active potassium transport by rabbit descending colon epithelium. J. Membr. Biol. 64:195-203.

19. Suzuki, Y., and K. Kaneko. 1989. Ouabain-sensitive $\mathrm{H}^{+}-\mathrm{K}^{+}$exchange mechanism in the apical membrane of guinea pig colon. Am. J. Physiol. 256:G979-G988.

20. Blanco, G., Z. J. Xie, and R. W. Mercer. 1993. Functional expression of the $\alpha_{2}$ and $\alpha_{3}$ isoforms of the Na,K-ATPase in baculovirus-infected insect cells. Proc. Natl. Acad. Sci. USA. 90:1824-1828.

21. Horisberger, J. D., P. Jaunin, M. A. Reuben, L. Lasater, D. C. Chow, J. G. Forte, G. Sachs, B. C. Rossier, and K. Geering. 1991. The H.K-ATPase $\beta$ subunit can act as a surrogate for the $\beta$ subunit of Na,K-pumps. J. Biol. Chem. 266:19131-19134

22. Marxer, A., B. Stieger, A. Quaroni, M. Kashgarian, and H. P. Hauri. 1989. $\left(\mathrm{Na}^{+}+\mathrm{K}^{+}\right)$-ATPase and plasma membrane polarity of intestinal epithelial cells: presence of a brush border antigen in the distal large intestine that is immunologically related to $\beta$ subunit. J. Cell Biol. 109:1057-1070.

23. Rajendran, V. M. M. Kashgarian, and H. J. Binder. 1989. Aldosterone induction of electrogenic sodium transport in the apical membrane vesicles of rat distal colon. J. Biol. Chem. 264:18638-18644. 